\title{
PENERAPAN MODEL KOOPERATIF TIPE TWO STAY TWO STRAY (TSTS) TERHADAP KEMAMPUAN KOMUNIKASI MATEMATIS
}

\author{
Arnida Sari $^{1}$, Memen Permata Azmi ${ }^{2}$ \\ 1,2 Jurusan Pendidikan Matematika, Universitas Islam Negeri Sultan Syarif Kasim Riau \\ Email penulis pertama: arnidasari@uin-suska.ac.id
}

\begin{abstract}
This study to examine whether there are differences in the ability of mathematic communication between students who learn to use cooperative model type TSTS with students who learn to use conventional method. This research type is Quasi Experimental Design research. The design used is the Pretest-Postest Control Group Design. The results showed that the average difference using t test at $\alpha=0.05$ obtained $t_{\text {count }}=2,32$ and $t_{\text {table }}=2,00$ so that $t_{\text {count }}<t_{\text {table }}$ not fulfilled. Thus it can be concluded that there are differences in the ability of mathematical communication between students who learn to use cooperative model type TSTS with students who learn to use conventional methods.
\end{abstract}

Keywords: Mathematics Learning, cooperative model type TSTS, mathematical Communication

\begin{abstract}
Abstrak
Penelitian ini bertujuan untuk menguji apakah terdapat perbedaan kemampuan komunikasi matematis antara mahasiswa yang belajar menggunakan model kooperatif tipe TSTS dengan mahasiswa yang belajar menggunakan metode konvensional. Jenis Penelitian ini adalah penelitian Quasi Eksperimental Design. Desain yang digunakan adalah Pretest-Postest Control Group Design. Hasil penelitian menunjukan bahwa perbedaan rata-rata menggunakan uji t pada $\alpha=0,05$ diperoleh $t_{\text {hitung }}=2,32$ dan $t_{\text {tabel }}=2,00$ sehingga $t_{\text {hitung }}<t_{\text {tabel }}$ tidak terpenuhi. Dengan demikian dapat disimpulkan bahwa terdapat perbedaan kemampuan komunikasi matematis antara mahasiswa yang belajar menggunakan metode model kooperatif tipe TSTS dengan mahasiswa yang belajar menggunakan metode konvensional.
\end{abstract}

Kata kunci: Pembelajaran Matematika, Model Kooperatif tipe TSTS, Komunikasi Matematis

Pendidikan matematika adalah salah satu bagian dari pendidikan nasional yang memiliki peranan yang sangat penting. Diantaranya adalah dapat menciptakan manusia-manusia yang berkualitas, cerdas, kreatif, terampil, produktif, bertanggung jawab dan berbudi luhur yang sangat berguna bagi pembangunan demi kemajuan bangsa dan negara. Manusia memperoleh ilmu pendidikan yang dapat dijadikan tuntunan dalam kehidupan dan dengan pendidikan orang menjadi maju serta mampu bersaing dengan Negara lain dalam segala bidang. Trianto (2012) mengutip bahwa tujuan pendidikan nasional yaitu untuk mengembangkan kemampuan dan membentuk watak serta peradaban yang bermartabat dalam rangka mencerdaskan kehidupan bangsa, agar menjadi manusia yang beriman dan bertaqwa kepada Tuhan Yang Maha Esa, berakhlak mulia, sehat, berilmu, cakap, kreatif, mandiri dan menjadi warga negara yang demokratis serta bertanggungjawab.

Adapun contoh kegiatan sehari-hari yang menggunakan matematika adalah menentukan waktu, menentukan jumlah transaksi jual beli, jumlah penduduk suatu wilayah, luas tanah dan bangunan serta masih banyak yang lainnya. Untuk menentukan keberhasilan penggunaan matematika dalam kehidupan, hal ini tidak terlepas dari kemampuan dalam mengkomunikasikan matematika yang merupakan salah satu bagian yang penting dari matematika. Komunikasi matematis sangat berguna 
dalam penyampaian informasi, sharing gagasan dan mengklasifikasikan pemahaman.

Kemampuan komunikasi matematis sangat diperlukan sejak dini oleh setiap peserta didik termasuk di dalamnya mahasiswa. Menurut NCTM (2000: 274) komunikasi matematis merupakan salah satu hal penting dalam berpikir matematis dan dapat membangun pemahaman matematis. Dengan memiliki kemampuan komunikasi matematis maka pengetahuan dan wawasan mahasiswa dapat membangun pemahaman baru dari pengetahuan sebelumnya.

Melalui komunikasi pula, konsep pemikiran dan wawasan mahasiswa akan semakin terbuka dan luas terhadap matematika karena mereka akan memandang matematika sebagai suatu bagian yang terintegrasi bukan sebagai sekumpulan topik yang terpisah-pisah, serta mengakui adanya keterkaitan atau hubungan dan aplikasi di dalam kehidupan atau lingkungan sekitar mereka.

Menurut Utari Sumarmo (2013), dalam belajar matematika mahasiswa dituntut memahami komunikasi antara ide-ide matematis dan antar matematika dan bidang studi lainnya karena topiktopik dalam matematika banyak memiliki relevansi dan manfaat dengan bidang lain, baik di sekolah maupun di luar sekolah. Jika mereka sudah mampu melakukan komunikasi antara beberapa ide matematis, maka mereka akan memahami setiap materi matematika dengan lebih dalam dan baik.

Sejalan dengan itu, Turmudi (Dahlan, 2011) menyatakan bahwa komunikasi merupakan bagian esensial dari matematika dan pendidikan matematika. Wahyudin (2008) juga menyatakan bahwa komunikasi adalah bagian esensial dari matematika dan pendidikan matematika. Kemampuan komunikasi matematis yang baik akan membantu mahasiswa dalam mengeksplorasi ide matematika yang dimilikinya, maka untuk meningkatkan kemampuan komunikasi matematis diperlukan metode pembelajaran yang tepat.

Berdasarkan hasil observasi pada mahasiswa terdapat masalah dalam pembelajaran khususnya pada aspek komunikasi matematis. Hal tersebut dapat dilihat dari gejala-gejala sebagai berikut: mahasiswa tidak bisa menyelesaikan persoalan matematika dengan menggunakan simbol-simbol matematika dan gambar,mahasiswa tidak bisa membuat apa yang diketahui dan ditanya dari soal dengan menggunakan notasi dan simbol matematika. mahasiswa tidak bisa menyampaikan argumen terhadap ide matematika yang dimilikinya, mahasiswa tidak bisa mendeskripsikan langkah-langkah pengerjaan soal dalam pembelajaran matematika, mahasiswa tidak bisa membuat kesimpulan dari penyelesaian soal matematika.

Selama ini dosen telah menggunakan berbagai metode untuk meningkatkan kemampuan komunikasi matematis, seperti metode ceramah, tanya jawab, dan resitasi, namun kemampuan komunikasi matematis mahasiswa belum meningkat. sehingga, diperlukan upaya untuk mendesain proses pembelajaran yang dapat meningkatkan kemampuan komunikasi matematis mahasiswa. Salah satu metode yang dapat digunakan untuk meningkatkan komunikasi mahasiswa adalah dengan menggunakan model kooperatif tipe TSTS.

Pembelajaran kooperatif yang memberikan kesempatan kepada kelompok untuk membagikan 
dan mengkomunikasikan hasil kerja mereka dengan kelompok lain sehingga penyebaran informasi lebih meluas dalam kelas tersebut adalah pembelajaran kooperatif tipe TSTS. Pembelajaran kooperatif tipe TSTS memberikan kesempatan kepada kelompok untuk membagikan hasil dan informasi dengan kelompok lain. Model pembelajaran kooperatif dengan tipe TSTS dalam penelitian ini adalah salah satu tipe pembelajaran kooperatif yang didalamnya dibentuk kelompok-kelompok heterogen yang baranggotakan 4 orang atau sering disebut dua tinggal dua tamu. Model pembelajaran kooperatif tipe TSTS (Two Stay Two Stray) atau dua tinggal dua tamu dikembangkan oleh Spencer Kagan (1990), salah satu kelebihan dari model pembelajaran kooperatif tipe TSTS (Two Stay Two Stray) ini yaitu mampu menciptakan dan menumbuhkan suasana belajar kelompok peserta didik untuk saling berbagi informasi dengan kelompok-kelompok peserta didik yang lain. Sehingga materi yang disampaikan oleh pendidik lebih menarik dan menyenangkan yang akan berdampak pada hasil belajar peserta didik (Ziyad, 2014). Menurut Saraswati (2012), salah satu model yang bisa diterapkan untuk meningkatkan pemecahan masalah matematis mahasiswa adalah model pembelajaran tipe TSTS. Berdasarkan hasil penelitian Suraji (2017) model pembelajaran kooperatif tipe TSTS (Two Stay Two Stray) dapat meningkatkan motivasi belajar matematika siswa dan Astuti (2016) model pembelajaran kooperatif tipe TSTS (Two Stay Two Stray) dapat meningkatkan hasil belajar matematika mahasiswa. Sedangkan Annisa dkk (2017) telah menyimpulkan dari hasil penelitiannya bahwa kemampuan komunikasi matematis mahasiswa tergolong rendah. Rezi dan Hayatun (2017) juga telah mencari hubungan antara kemampuan pemecahan masalah matematis dengan kemampuan komunikasi matematis siswa. Dengan adanya interaksi positif antar kelompok, maka akan melatih kemampuan mahasiswa dalam pemecahan masalah, dan memacu terbentuknya ide baru serta memperkaya perkembangan intelektual mahasiswa.

\section{METODE}

\section{Jenis Penelitian}

Jenis penelitian ini adalah penelitian kuantitatif dengan pendekatan penelitian Quasi Eksperimental Design yaitu desain yang mempunyai kelompok kontrol tetapi tidak berfungsi sepenuhnya untuk mengontrol variabel-variabel luar yang mempengaruhi pelaksanaan eksperimen.

\section{Desain Penelitian}

Desain penelitian ini menggunakan desain penelitian "Pretest-Posttest Control Group Design".

\section{Waktu, Tempat dan Subjek Penelitian}

Penelitian ini dilaksanakan pada Program Studi Pendidikan Matematik Fakultas Tarbiyah dan Keguruan UIN Suska Riau. Sampel pada penelitian ini adalah mahasiswa semester V sebanyak 6 kelas dan diambil sebanyak 2 lokal untuk diteliti.

\section{Instrumen Penelitian dan Teknik Pengumpulan Data}

Pengambilan sampel dipilih dua lokal yaitu lokal C dan D dengan menggunakan teknik purposive 
sampling. Purposive Sampling yaitu teknik pengambilan sampel dengan memikirkan pertimbangan tertentu. Adapun teknik pengumpulan data pada penelitian ini yaitu dengan melakukan pengamatan atau observasi, tes komunikasi matematis dan dokumentasi. Pengamatan atau observasi dilakukan oleh dosen dengan cara menggunakan instrumen yang sudah dirancang sebelumnya. Teknik observasi menggunakan lembar pengamatan dosen dan mahasiswa untuk mengamati kegiatan dosen dan mahasiswa yang diharapkan muncul dalam pembelajaran matematika dengan model pembelajaran kooperatif tipe TSTS (Two Stay Two Stray) yang dilakukan setiap kali pertemuan. Untuk mengukur kemampuan komunikasi matematis mahasiswa pada penelitian ini menggunakan tes berbentuk uraian dengan cara memberikannya pada kedua kelas sampel sebelum dan setelah diberi perlakuan. Sebelum tes dilakukan, soal tes harus harus terlebih dulu diuji sehingga memenuhi beberapa syarat seperti validitas, reliabilitas, daya pembeda dan tingkat kesukaran soal. Sedangkan dokumentasi digunakan untuk memperoleh data langsung dari tempat penelitian dan data yang relevan dengan penelitian ini.

\section{Teknik Analisis Data}

Setelah soal tes diujicobakan, maka tahap selanjutnya adalah menganalisis hasil uji coba instrument tersebut yang meliputi:

\section{Validitas}

Suatu instrumen dikatakan valid apabila instrumen tersebut dapat mengukur secara tepat sesuai dengan keadaan yang sebenarnya. Validitas adalah suatu ukuran yang menunjukkan tingkat-tingkat kesahihan suatu instrumen (Hartono, 2010). Dalam menentukan validitas digunakan rumus Korelasi Product Moment.

Hasil dari analisis validasi soal yang menunjukkan tingkat-tingkat kesahihan soal dapat dilihat pada tabel berikut.

\section{Tabel 1 Hasil Validitas Soal}

\begin{tabular}{|c|c|c|c|c|}
\hline $\begin{array}{l}\text { No. } \\
\text { Item } \\
\text { Soal }\end{array}$ & $\begin{array}{l}\text { Koefisien Korelasi } \\
r_{\text {hitung }}\end{array}$ & $\begin{array}{l}\text { Harga } \\
t_{\text {hitung }}\end{array}$ & Harga $t_{\text {tabel }}$ & Keputusan \\
\hline 1 & 0,430 & 2,814 & 1,69236 & Valid \\
\hline 2 & 0,745 & 7,284 & 1,69236 & Valid \\
\hline 3 & 0,705 & 5,411 & 1,69236 & Valid \\
\hline 4 & 0,527 & 2,718 & 1,69236 & Valid \\
\hline 5 & 0,236 & 1,439 & 1,69236 & Tidak Valid \\
\hline 6 & 0,656 & 3,832 & 1,69236 & Valid \\
\hline
\end{tabular}

Dari tabel dapat dilihat bahwa dari sembilan soal yang diujicobakan, jumlah soal yang valid berjumlah delapan butir soal dan hanya satu soal yang tidak valid. Oleh karena itu, tes tersebut layak digunakan sebagai instrumen penelitian 


\section{Reabilitas}

Reliabilitas adalah tingkat atau derajat konsistensi dari suatu instrument (Arifin, 2012). Pengukuran reabilitas dengan yaitu menggunakan rumus Alpha. Berdasarkan hasil uji coba reliabilitas butir soal secara keseluruhan diperoleh koefisien reliabilitas tes sebesar 0,7611. Jika dibandingkan dengan nilai $r_{\text {tabel }} 0,436$, berarti Harga $r_{\text {hitung }}>r_{\text {tabel }}$ atau $0,7611>0,436$, maka keputusan seluruh butir soal adalah reliabel dengan kriteria "tinggi".

\section{Taraf Kesukaran}

Perhitungan tingkat kesukaran soal adalah pengukuran seberapa besar derajat kesukaran suatu soal (Suharsimi, 2011).

\section{Tabel 2 Hasil Perhitungan Tingkat Kesukaran Soal}

\begin{tabular}{lll}
\hline No. & Tingkat Kesukaran Soal & Interpretasi \\
\hline $\mathbf{1}$ & 0,794 & Terlalu Mudah \\
\hline $\mathbf{2}$ & 0,547 & Cukup (Sedang) \\
\hline $\mathbf{3}$ & 0,667 & Cukup (Sedang) \\
\hline $\mathbf{4}$ & 0,575 & Cukup (Sedang) \\
\hline $\mathbf{5}$ & 0,426 & Cukup (Sedang) \\
\hline $\mathbf{6}$ & 0,275 & Terlalu Sukar \\
\hline
\end{tabular}

\section{Daya Pembeda}

Perhitungan daya pembeda adalah pengukuran sejauh mana suatu butir soal mampu membedakan peserta didik yang belum atau kurang menguasai kompetensi berdasarkan kriteria tertentu (Suharsimi, 2011).

Tabel 3 Hasil Perhitungan Daya Pembeda Soal

\begin{tabular}{lll}
\hline $\begin{array}{l}\text { Nomor } \\
\text { Soal }\end{array}$ & Daya Pembeda & Interpretasi \\
\hline $\mathbf{1}$ & 0,222 & Cukup \\
\hline $\mathbf{2}$ & 0,294 & Cukup \\
\hline $\mathbf{3}$ & 0,583 & Baik \\
\hline $\mathbf{4}$ & 0,888 & Baik Sekali \\
\hline $\mathbf{5}$ & 0,611 & Baik \\
\hline $\mathbf{6}$ & 0,305 & Cukup \\
\hline
\end{tabular}

Berdasarkan hasil analisis terhadap validitas, reliabilitas, tingkat kesukaran dan daya pembeda soal, dapat disimpulkan bahwa tes yang telah diujicobakan dapat digunakan sebagai instrumen pada penelitian ini.

\section{HASIL DAN PEMBAHASAN}

Dari hasil pengujian yang diperoleh setelah data dianalisis, menunjukkan bahwa terdapat perbedaan antara kemampuan komunikasi matematis mahasiswa yang menggunakan model pembelajaran kooperatif tipe TSTS (Two Stay Two Stray) dengan mahasiswa yang belajar menggunakan pembelajaran konvensional. Adanya perbedaan menunjukkan model pembelajaran 
kooperatif tipe TSTS (Two Stay Two Stray) berpengaruh terhadap kemampuan komunikasi matematis mahasiswa. Perbedaan mean kelas eksperimen dan kelas kontrol yaitu kelas eksperimen yang menggunakan model pembelajaran kooperatif tipe TSTS (Two Stay Two Stray) adalah 80 dan kelas kontrol yang menggunakan pembelajaran konvensional adalah 73 menunjukkan mean kelas eksperimen lebih tinggi dari mean kelas kontrol. Hal ini dapat disimpulkan bahwa penerapan model pembelajaran kooperatif tipe TSTS (Two Stay Two Stray) dalam pembelajaran matematika memiliki pengaruh positif terhadap kemampuan komunikasi matematis.

Salah satu faktor penyebab adanya pengaruh model pembelajaran kooperatif tipe TSTS (Two Stay Two Stray) terhadap kemampuan komunikasi matematis mahasiswanya adalah mahasiswa dilibatkan secara aktif dalam pembelajaran sehingga mahasiswa mampu mengkomunikasikan pemahamannya dan ide-ide melalui pengerjaan soal maupun presentasi yang dilakukan sebelumnya. Hal ini dikarenakan mahasiswa belum terbiasa untuk saling berkomunikasi dan berbagi informasi. Sebagai contoh, dalam diskusi awalnya mahasiswa merasa dituntut untuk memahami dan mengkomunikasikan secara keseluruhan materi yang dipelajari baik secara tulisan maupun dengan lisan. Sebahagian besar mahasiswa masih malu-malu dan bingung bagaimana mengkomunikasikan permasalahan suatu materi tanpa harus menunjukkan jawaban langsung. Mahasiswa juga segan untuk mengeluarkan pendapatnya karena takut diejek oleh teman-temannya. Namun hal ini berjalan hanya pada awal pembelajaran saja, dalam beberapa pertemuan berikutnya mahasiswa-mahasiswa secara natural berusaha memahami dan mengkomunikasikan apa yang mereka pelajari dengan gaya bahasa dan belajarnya sendiri tanpa merasa ada unsur paksaan.

Dari uraian di atas, dapat dijelaskan bahwa secara keseluruhan mahasiswa yang berada dalam kelas dengan kemampuan yang heterogen dapat menyerap pelajaran dan mengkomunikasikan materi dengan baik sehingga kemampuan komunikasi matematis mahasiswa dapat meningkat. Analisis ini mendukung rumusan masalah yang diajukan yaitu terdapat perbedaan kemampuan komunikasi matematis mahasiswa yang belajar menggunakan model pembelajaran kooperatif tipe TSTS (Two Stay Two Stray) dengan mahasiswa yang menggunakan pembelajaran konvensional.

Penelitian ini masih banyak kelemahan dan keterbatasan yang sulit dikendalikan. Adapun keterbatasan pada saat penelitian yaitu: Penelitian hanya dilakukan pada populasi Mahasiswa semester V Program Studi Pendidikan Matematika sehingga kurang dapat digeneralisasikan pada mahasiswa Program Studi Pendidikan Matematika semester lain. Adanya faktor-faktor lain yang ikut mempengaruhi kemampuan komunikasi matematis mahasiswa yang tidak diteliti. Selain itu hasil yang diperoleh dalam kemampuan komunikasi matematis pada penelitian ini tidak cukup untuk menggeneralisasikan pada prestasi matematika secara keseluruhan. Namun demikian, keterbatasan penelitian ini tidak mengurangi kebenaran hasil penelitian yang diperoleh, sehingga dapat dipergunakan dalam meningkatkan kemampuan komunikasi matematis mahasiswa menjadi lebih baik. 


\section{KESIMPULAN}

Terdapat perbedaan kemampuan komunikasi matematis mahasiswa yang menggunakan model pembelajaran kooperatif tipe TSTS (Two Stay Two Stray) dengan mahasiswa yang menggunakan pembelajaran konvensional. Selain itu, nilai rata-rata kelas eksperimen lebih tinggi pada nilai rata-rata kelas kontrol. Hal ini berarti bahwa nilai rata-rata kelas eksperimen lebih baik dari pada nilai rata-rata kelas kontrol. Dengan demikian dapat disimpulkan bahwa model pembelajaran kooperatif tipe TSTS (Two Stay Two Stray) memberikan pengaruh positif terhadap kemampuan komunikasi matematis mahasiswa.

Melalui tulisan ini peneliti mengajukan beberapa saran yang berhubungan dengan pembelajaran kooperatif tipe TSTS (Two Stay Two Stray) agar dapat memberikan kesempatan kepada dosen untuk menerapkan model pembelajaran yang bervariasi salah satunya adalah menerapkan model pembelajaran kooperatif tipe TSTS (Two Stay Two Stray). Karena jika kemampuan komunikasi matematis mahasiswa dapat membaik tentu akan membantu hasil belajar mahasiswa itu sendiri.

\section{DAFTAR PUSTAKA}

Annisa dkk. (2017). Pengaruh Penerapan Metode Pembelajaran Kelompok Buzz terhadap Kemampuan Komunikasi Matematis Siswa. Suska Journal of Mathematics Education, 3 (2), 111-118.

Astuti. (2016). Pengaruh Model Pembelajaran Kooperatif tipe Two Stay Two Stray (TSTS) terhadap Hasil Belajar Matematika Siswa Kelas VII SMP Negeri 2 Bangkinang Kota. Journal Cendekia : Jurnal Pendidikan Matematika, 1 (2), 11-28.

Dahlan, J. A. (2011). Analisis Kurikulum Matematika Edisi 1. Buku Materi Pokok: Universitas Terbuka.

Hartono. (2010). Analisis Item Instrumen. Pekanbaru: Zanafa Publishing.

National Council of Teachers of Mathematics (NCTM). (2000). Principles and standard for School Mathematics. Reston: NCTM.

Rezi Ariawan dan Hayatun Nufus. (2017). Hubungan Kemampuan Pemecahan Masalah Matematis dengan Kemampuan Komunikasi Matematis Siswa. Jurnal THEOREMS (The Original Research of Mathematics), 1 (2), 82-91.

Saraswati dkk. (2012). Penerapan pembelajaran two stay two stray (TSTS) terhadap kemampuan pemahaman konsep dan minat. Journal of Mathematics Education Unnes.

Suharsimi Arikunto. (2011). Dasar-dasar Evaluasi Pendidikan. Yogyakarta: PT Bumi Aksara.

Suraji dan Arnida Sari. (2017). Penerapan Model Kooperatif tipe Two Stay Two Stray (TSTS) dalam Upaya Meningkatkan Kemampuan Pemecahan Masalah Matematis Siswa SD. Suska Journal of Mathematics Education, 3 (2), 67-73.

Trianto. (2012). Mendesain Model Pembelajaran Inovatif-progresif Jakarta: Kencana Grup. 
Penerapan Model Kooperatif Tipe Two Stay Two Stray (TSTS) Terhadap Kemampuan Komunikasi Matematis, Arnida Sari, Memen Permata Azmi

Utari Sumarmo. (2013). Kumpulan Makalah Berpikir dan Disposisi Matematik Serta Pembelajarannya. Bandung: UPI.

Wahyudin. (2008). Pembelajaran dan Model-model Pembelajaran. Bandung: UPI Press. Zainal Arifin. (2012). Evaluasi Pembelajaran Prinsip, Teknik, Prosedur. Bandung. Remaja Rosdakarya.

Ziyad Habibi. (2014). Pengaruh Model Pembelajaran Kooperatif Tipe Tsts (Two Stay Two Stray) Terhadap Hasil Belajar Siswa Pada Mata Pelajaran Teknik Elektronika Dasar Di Smk Negeri 1 Jetis Mojokerto. E-jourrnal UNESA, 3, (3). 